
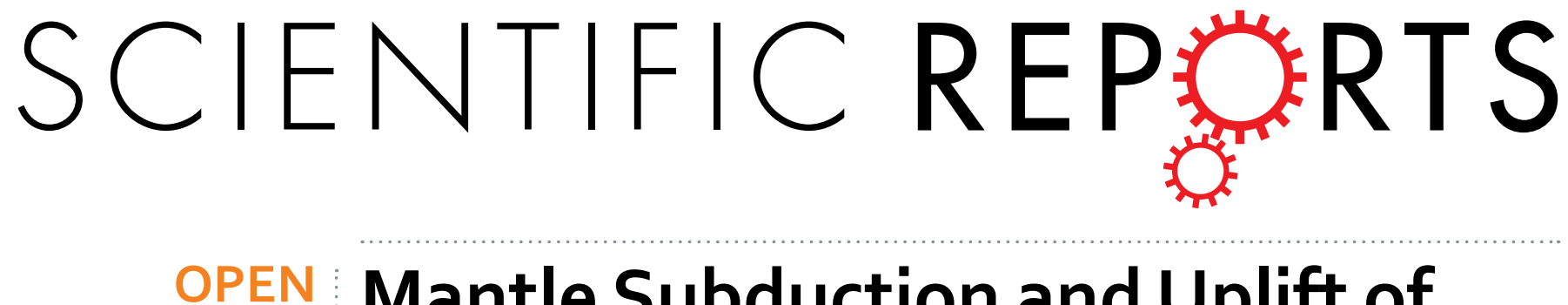

\title{
Mantle Subduction and Uplift of Intracontinental Mountains: A Case Study from the Chinese Tianshan \\ Mountains within Eurasia
}

Received: 05 January 2016

Accepted: 09 June 2016

Published: 29 June 2016
Jinyi Li ${ }^{1}$, Jin Zhang ${ }^{1}$, Xixi Zhao ${ }^{2,3}{ }^{3}$, Mei Jiang ${ }^{1}$, Yaping Li ${ }^{1}$, Zhixin Zhu ${ }^{1}$, Qianwen Feng ${ }^{1}$, Lijia Wang ${ }^{1}$, Guihua Sun ${ }^{1}$, Jianfeng Liu ${ }^{1} \&$ Tiannan Yang ${ }^{1}$

The driving mechanism that is responsible for the uplift of intracontinental mountains has puzzled geologists for decades. This study addresses this issue by using receiver function images across the Chinese Tianshan Mountains and available data from both deep seismic profiles and surface structural deformation. The near-surface structural deformation shows that the Tianshan crust experienced strong shortening during the Cenozoic. The receiver function image across the Tianshan Mountains reveals that the lithosphere of the Junggar Basin to the north became uncoupled along the Moho, and the mantle below the Moho subducted southwards beneath the northern part of the Tianshan Mountains, thereby thickening the overlying crust. Similar deep structures, however, are not observed under the Tarim Basin and the adjacent southern Tianshan Mountains. This difference in the deep structures correlates with geomorphological features in the region. Thus, a new model of mantle subduction, herein termed M-type subduction, is proposed for the mountain-building processes in intracontinental compressional settings. The available geomorphological, geological and seismic data in the literatures show that this model is probably suitable for other high, linear mountains within the continent.

Mountains and basins are two types of basic tectono-geomorphologic units on the Earth. How and why mountains on continents uplift has challenged geologists since the late $1800 \mathrm{~s}^{1}$. With the tremendous advance of the theory of the plate tectonics, geologists now recognize that mountains on continental margins, such as those around the Pacific ocean, are products of the subduction of oceanic lithospheric plates under continental plates (B-type subduction, for short), and that intercontinental mountains, such as the Himalayas and Alps, are the products of the subduction of one continental plate under another (A-type subduction). However, the origins of some intracontinental mountains, such as the Petermann and Alice Springs orogens in central Australia and the Tianshan Mountains in central Eurasia, still puzzle geologists ${ }^{2-8}$. Does the uplift of intracontinental mountains originate from the subduction of lithospheric plates similar to beneath continent-marginal and intercontinental mountains? If so, what type of subduction occurs? Does the entire lithospheric plate subduct, similar to A-type subduction between two continents, or does only the mantle part of the lithosphere subduct?

This study focuses on the Chinese Tianshan Mountains (Segment C in Fig. 1B) to discuss the driving mechanism that is responsible for the uplift of linear intracontinental mountains by using data on deep structures as revealed by seismic receiver function images in combination with geomorphologic features, structural deformation near the surface, and other available seismic data.

\section{Geography and Regional Geology of the Tianshan Mountains}

The Tianshan Mountains in the interior of the Eurasian continent extend from Uzbeckstan eastwards through Kyrgyzstan and Northwest China to southwestern Mongolia, stretching nearly $3000 \mathrm{~km}$ in length and 200-400 km in width. This range exhibits distinctive geomorphological characteristics, and can be subdivided into five segments from east to west: Segment A, which is located west of the NW-trending Talas-Ferghana fault, features

${ }^{1}$ Institute of Geology, Chinese Academy of Geological Sciences, Beijing 100037, China. ${ }^{2}$ School of Ocean and Earth Sciences, State Key Lab of Marine Geology, Tongji University, Shanghai 200092, China. ${ }^{3}$ Department of Earth and Planetary Sciences, University of California, Santa Cruz, California 95064, USA. Correspondence and requests for materials should be addressed to J.L. (email: jyli@cags.ac.cn) 


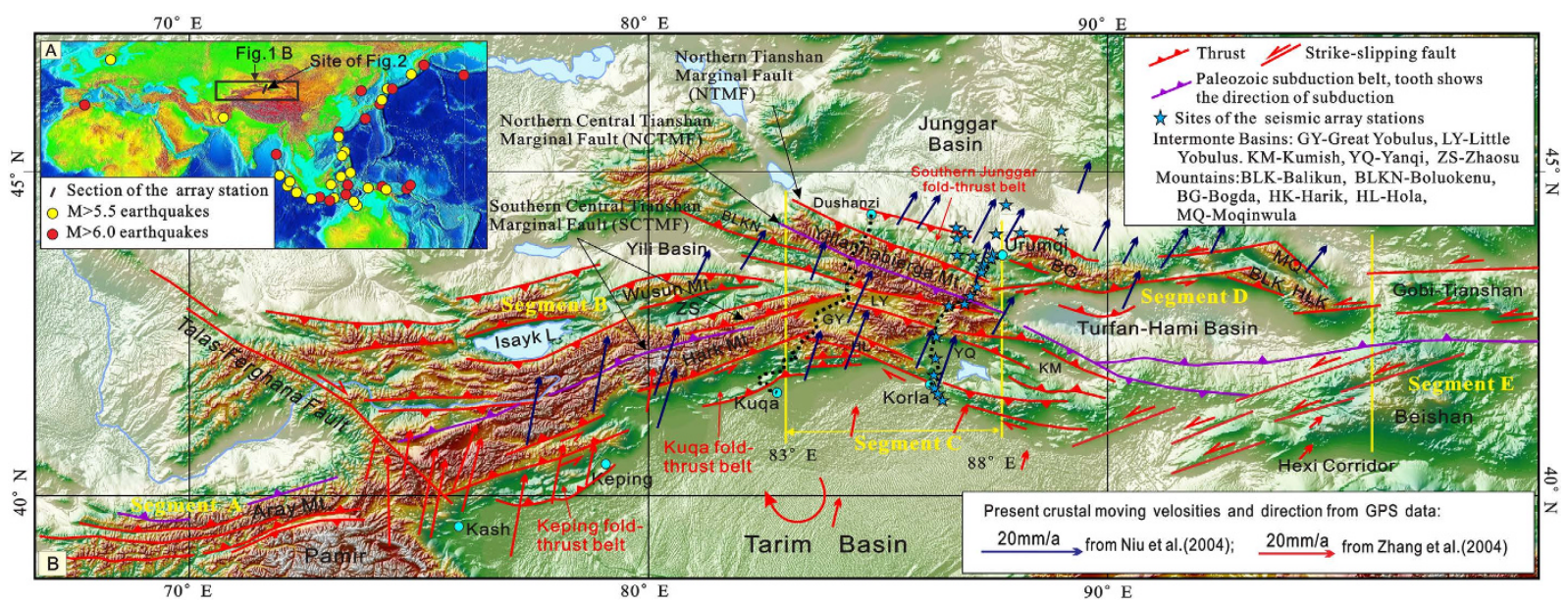

Figure 1. Geomorphological and Tectonic features of the Tianshan Mountains. (A) Study area and earthquakes that were used for the formation of the receiver function image, which were selected from more than 500 earthquakes from a USGS database that was created during this study's data collection. (B) Geomorphologic and tectonic features of the Tianshan Mountains, which show their segmentation with latitude and zoning with longitude, Cenozoic faults ${ }^{36}$ and Paleozoic subduction zones ${ }^{9,11-14,62}$, the asymmetry of structural deformation near the surface on both sides ${ }^{12}$, the crust's velocity and direction from GPS data ${ }^{60,61}$, and the clockwise rotation of the Tarim Blocks ${ }^{22,40}$. The primary DEM data that were used for the geomorphological features in (B) are in the SRTM GTOPO 30 format and were provided by NASA and downloaded from http://glcf.umiacs.umd.edu in 2010. The figure was generated using ArcMap v10.1 (http://www.esrichina.com.cn/softwareproduct/ArcGIS/) and processed by CorelDRAW X7 (http://www.coreldraw.com/cn/product/graphic-design-software/?hptrack=cn2hr1\&_ga=1.5 9748394.665041398.1450858064).

a southward arc-like linear mountain range; Segment B features NE-trending linear mountains to the south and alternating ranges and basins to the north; Segment $C$ exhibits the opposite geomorphologic framework as Segment B; Segment D features a high, curved mountain range to the north, a single large basin in the center, and lower hills and the Gobi Desert to the south; and Segment E features lower hills and desert basins (Fig. 1B). Segments C and D, and most parts of Segments B and E in the mountains are located within China, between the Junggar Basin to the north and the Tarim Basin to the south. These features possibly imply a variety of origins and uplift mechanisms for these intracontinental mountains.

Geologically, the crust of the Tianshan Mountains is composed of a mosaic of Paleozoic oceanic and island arc fragments ${ }^{9-14}$. Mesozoic and Cenozoic terrestrial sediments accumulated in intermontane basins in the Chinese part of the mountains, and Cenozoic thrust faults are present along the boundaries of all the basins ${ }^{15-21}$ (Fig. 1B). Interestingly, a Cenozoic basin-verging fold-and-thrust belt that is similar to that in the foreland basin of the collisional orogenic belt occurs in the piedmont of the linear mountains in Segments B and $C^{22-32}$ (Fig. 1B). These faults and folds are indicative of the intense crustal shortening that occurred in these areas during the Cenozoic.

The crust of the Junggar Basin to the north is composed of Paleozoic island-arc complexes and overlaying Permian to Quaternary terrestrial deposits ${ }^{33}$. A Paleozoic ocean was located between the island-arc and the Yili Block to the south, and B-type subduction belts occurred along the southern and northern margins of the ocean ${ }^{12}$. Additionally, the crust of the Tarim Basin to the south consists of Mesozoic to Cenozoic terrestrial deposits, Paleozoic passive-margin sedimentary sequences and Precambrian basement ${ }^{34}$. Furthermore, a northward-directed late Paleozoic B-type subduction zone existed between the Tarim Basin and the Tianshan Mountians ${ }^{9-12,14}$.

The Cenozoic uplift of the Chinese part of the Tianshan Mountains is considered to be a distance-response to the collision of the Indian and Eurasian plates ${ }^{17,23,29,35-38}$. Various tectonic models of the uplift of these mountains have been proposed, including the subduction of basins on both sides of the mountains ${ }^{39}$, northward movements and the clockwise rotation of the Tarim Basin ${ }^{22,40}$, the northward indentation of the Pamir ${ }^{15,32}$, and mantle convection beneath the mountains under the compressional setting ${ }^{41}$. However, none of these models used a high-resolution data base of deep-seated structure and thus could not provide a satisfactory explanation for the origin of the unique geographical and geological features in these mountains.

\section{Receiver Function Images and the Deep Structure of the Profile between Urumuqi and Korla}

The receiver function method has been a main approach during the late twentieth century for understanding the deep structure of continental lithosphere ${ }^{42-44}$. The receiver function image of a profile across Segment $\mathrm{C}$ of the Tianshan Mountains along the highway from Urumuqi to Korla is one result of the broadband seismic probing project of eastern Xinjiang that was conducted out from May 2002 to November $2004^{45,46}$. Some new information regarding the deep structures of these mountains can be obtained from the images. Geological interpretations of the image are shown in Fig. 2B and are briefly discussed below. 

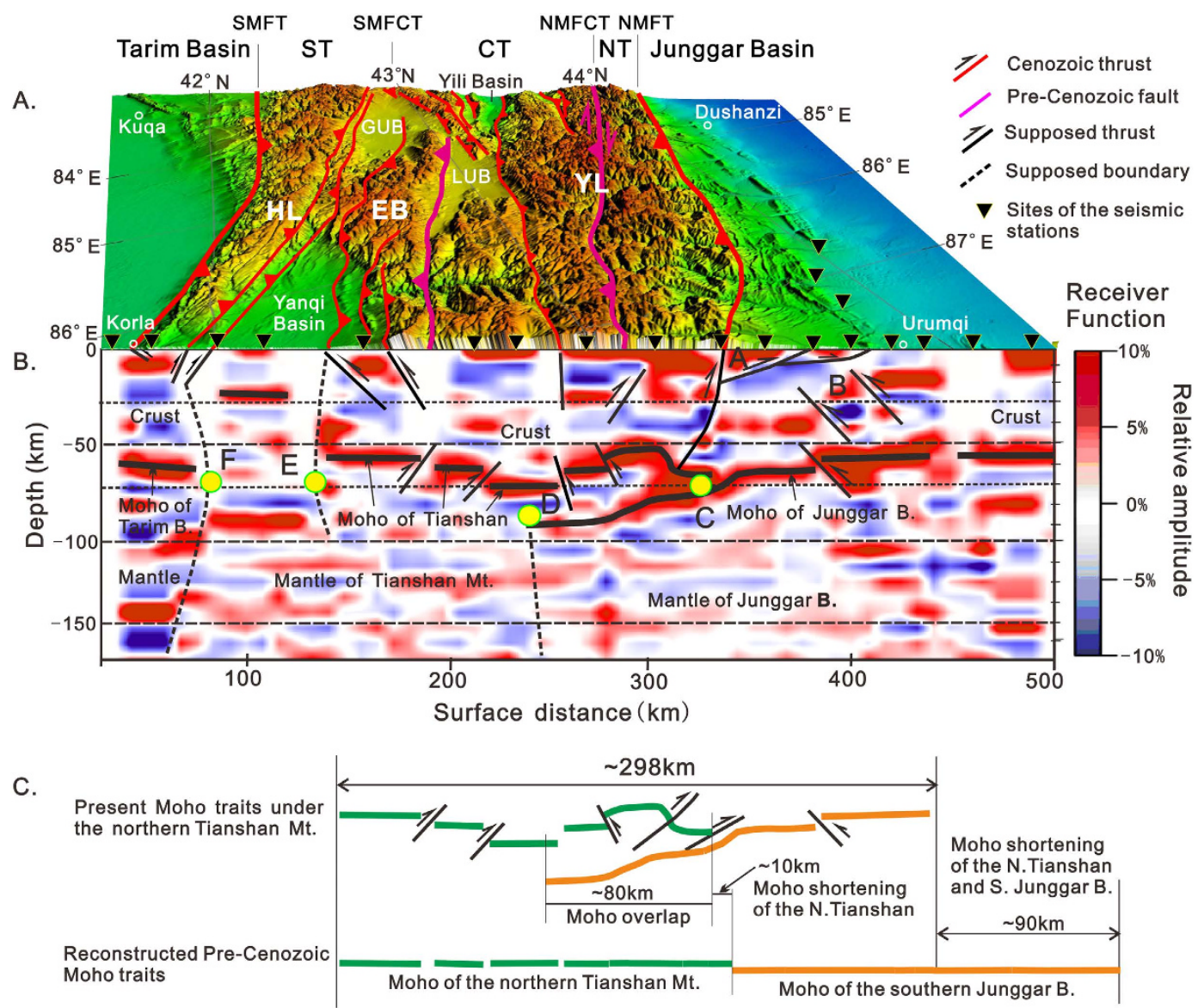

Figure 2. Receiver function image and its geological interpretation of Chinese Tianshan Mountains. (A) Geomorphologic features of Segment C in the Tianshan Mountains. (B) Receiver function image across the mountains along the highway from Urumuqi in the north to Korla in south and its geological interpretation; the red and blue colors show positive and negative stacking amplitudes, respectively. (C) Estimates of Cenozoic crustal shortening of northern part in the Tianshan Mountains. Abbreviations of the tectonic units and their boundaries near the surface as suggested by geologists: NT-North Tianshan, CT-Central Tianshan, ST-South Tianshan, NMFT-northern marginal fault of North Tianshan, NMFCT- northern marginal fault of Central Tianshan, SMFCT- southern marginal fault of Central Tianshan, SMFT- southern marginal fault of South Tianshan. Present-day ranges and basins: YL-Yilianhabierga Mt., EB-Erbin Mt., HL-Hola Mt., GYB-Great Yobulus Basin, LYB-Little Yobulus Basin. The primary DEM data that were used for the geomorphological features in (A) are in the SRTM GTOPO 30 format and were provided by NASA and downloaded from http:// glcf.umiacs.umd.edu in 2010. The figure was generated by using ArcMap v10.1 (http://www.esrichina.com.cn/ softwareproduct/ArcGIS/) and processed by CorelDRAW X7 (http://www.coreldraw.com/cn/product/graphicdesign-software/?hptrack=cn2hr1\&_ga $=1.59748394 .665041398 .1450858064)$.

Two obvious features are observed in the receiver function image (Fig. 2B). First, a strong P- to $\mathrm{S}$-wave-conversion belt is present at depths of approximately $50-70 \mathrm{~km}$ below the surface, which is roughly concordant with the depth of the Moho as inferred from gravity anomalies ${ }^{47}$ and deep seismic reflection data ${ }^{48,49}$. Second, the crustal structure and tectonic features along the profile are heterogeneous and may be divided into three parts from north to south, i.e., the southern margin of the Junggar Basin, the northern part of the Tianshan Mountains, and the southern part of the Tianshan Mountains.

Southern Margin of the Junggar Basin. The Moho under the southern Junggar Basin (north of point C in Fig. 2B) tilts to the south, transitioning from a depth of approximately $50 \mathrm{~km}$ in the southern Junggar Basin to a depth of nearly $70 \mathrm{~km}$ at the junction between the Junggar Basin and the Tianshan Mountains. The crust above the Moho is characterized by four structural layers, which are outlined in the receiver function images. The uppermost layer (point A in Fig. 2B) is a northward-thinning wedge with a north-verging imbricated-thrust structure. The other three layers are roughly parallel to the Moho. A layered structure below the Moho is also clear but becomes blurred to the south. Interestingly, south-verging thrusts that cut the Moho are present in the southern Junggar Basin (point B in Fig. 2B). 
Northern Part of the Tianshan Mountains. The Moho exhibits concave-upward deformation under the northern part of the Tianshan Mountains between the Junggar Basin to the north and the Yanqi Basin to the south (the region between points $\mathrm{C}$ and $\mathrm{E}$ in Fig. 2B), and an up-warp along the northern margin of the concavity. The Moho in the northern (right side of point D in Fig. 2B) and southern (left side of the point D in Fig. 2B) parts is located at approximately 50-60 km depth, whereas the Moho in the central part (point D in Fig. 2B) lies at a depth of approximately $75 \mathrm{~km}$. Faults bound the northern and southern sides of the concavity, with thrust directions that are oriented toward the core of the mountains. This thrusting likely contributed to the Moho deformation and crustal shortening. The southward-dipping Moho of the Junggar Basin appears to underlie the Moho of the Tianshan Mountains in the region between points C and D (Fig. 2B), which contains the highest peak in Segment $\mathrm{C}$ of the Tianshan Mountains on the surface.

No clear layered structures can be seen under the Moho in the northern part of the Tianshan Mountians. However, a northward-dipping interface occurs at the mantle below the point $\mathrm{D}$ in Fig. 2B, possibly representing the southern boundary of the Junggar mantle.

Southern Part of the Tianshan Mountains. The southern part of the Tianshan Mountains along the profile can be divided into two parts: the Yanqi Basin to the north and Hola Mt. to the south.

Under the Yanqi Basin (between points $\mathrm{E}$ and F in Fig. 2B), no Moho is connected to interfaces on either side, but two distinct transfer interfaces can be seen at depths of approximately $20 \mathrm{~km}$ and $80 \mathrm{~km}$. The geological implications of these interfaces are not certain at present. A relatively weak converted wave surface is present between these two layers and tilted to the north, especially in the $40-50 \mathrm{~km}$ depth range. An even weaker converted wave surface occurs at approximately $60 \mathrm{~km}$ depth. Whether these two surfaces correspond to the modified Moho of the Tianshan Mountains $(40-50 \mathrm{~km})$ and Tarim Basin $(60 \mathrm{~km})$ remains to be investigated.

The receiver function image under the Hola Mt. region is characterized by an obvious layered structure. A strong conversion belt with a moderately northward dip is located at a depth of approximately $60 \mathrm{~km}$. This feature is interpreted to be the Moho of the Tarim Basin.

\section{Estimates of Cenozoic Crustal Shortening}

Previous investigations and estimates of the Cenozoic crustal shortening of the Tianshan Mountains and adjacent regions mainly examined in the piedmonts on the flanks of the range ${ }^{23-26,31}$. The relative lack of data from the interior of the mountains because of natural geomorphology constraints has hampered our knowledge of the crustal shortening in the mountains.

The available geological data reveal that the crust of the Tianshan Mountains and adjacent regions are a mosaic of Paleozoic island arcs and oceanic remains that were amalgamated during the Late Paleozoic ${ }^{9-14}$ and that peneplanation occurred at the end of the Jurassic ${ }^{50}$. According to the features in the studied image, we suppose that the present Moho likely formed following the peneplanation at the end of the Jurassic and that its dislocations and overlap are records of intracontinental orogenesis during the Cenozoic. Thus, using the Moho as a key marker bed provides a new approach to study and estimate the Cenozoic crustal shortening in this region.

As shown in Fig. 2C, we obtained a Cenozoic crustal shortening estimate of $\sim 90 \mathrm{~km}$ for the northern part of the Tianshan Mountains and its northern adjacent region according to the above suppositions and by using the balanced section technique from structural geology ${ }^{51}$. In detail, approximately $80 \mathrm{~km}$ of the shortening originated from the overlap of the Moho between the northern Tianshan Mountains and the Junggar Basin, and the remaining $10 \mathrm{~km}$ originated from the dislocation and bending deformation of the Moho under the northern Tianshan Mountains. However, the above estimate is probably the minimum shortening of the crust in the northern part of the Tianshan Mountains because this feature originated from the deformation of the Moho in the north segment of the 2-D seismic profile and because we do not know the detail of the deformation of the Moho.

\section{Discussion and Conclusions}

The northern part of the above receiver function image is reliable and authentic because of the high quality of the collected seismic data, and the rationality of data-processing. However, some uncertainty is present for its southern part because of natural disturbances from the thicker Cenozoic sediments in the Yanqi Basin. However, the difference in the deep structures between the northern and southern parts of the mountains should be an objective fact based on the available seismic data. For example, Shao et al. ${ }^{52}$ reported that thicker crust and more complex deep-seated structures are present in the northern part of the same profile, and no trace of Paleozoic subduction or plate collision is present in the deep structures alone the profile. However, these authors did not separate Cenozoic structures from Paleozoic structures, and reached the conclusion that neither subduction nor collision between plates occurred in the region during the Phanerozoic. The cut-off and lifting but absence of overlap of the Moho below the Yanqi Basin in the southern part of the profile can be observed in the image that was published by Mi et al. ${ }^{53}$, which indicated thinner crust in the basin compared to that on either side. However, we did not deduce any information from the image regarding the subduction of the Tarim lithosphere under the basin during the Cenozoic as supposed by Mi et al. ${ }^{53}$.

Another highway through the Tianshan Mountains is present approximately $200 \mathrm{~km}$ westwards from the above profile. Some seismic investigations into the deep structures of the mountains have been performed along this highway. The deep structural profiles that were obtained by these investigations ${ }^{54-58}$ showed that the crust in the northern Tianshan Mountains is thicker and characterized by more complex structures; below the crust, is a cut-off in the Moho and a southward-dipping layer of high velocity. A high velocity archy-like layer occurs in the lithosphere below the southern parts of the mountains, and a nearly vertical velocity structure exists in the junction between the Tarim Basin and the Tianshan Mountains.

The deep-source earthquakes in this region reveal the occurrence of structural deformation near the Moho under the northern part of Segment C in the Tianshan Mountains ${ }^{39,59}$. The surface structural deformation, 


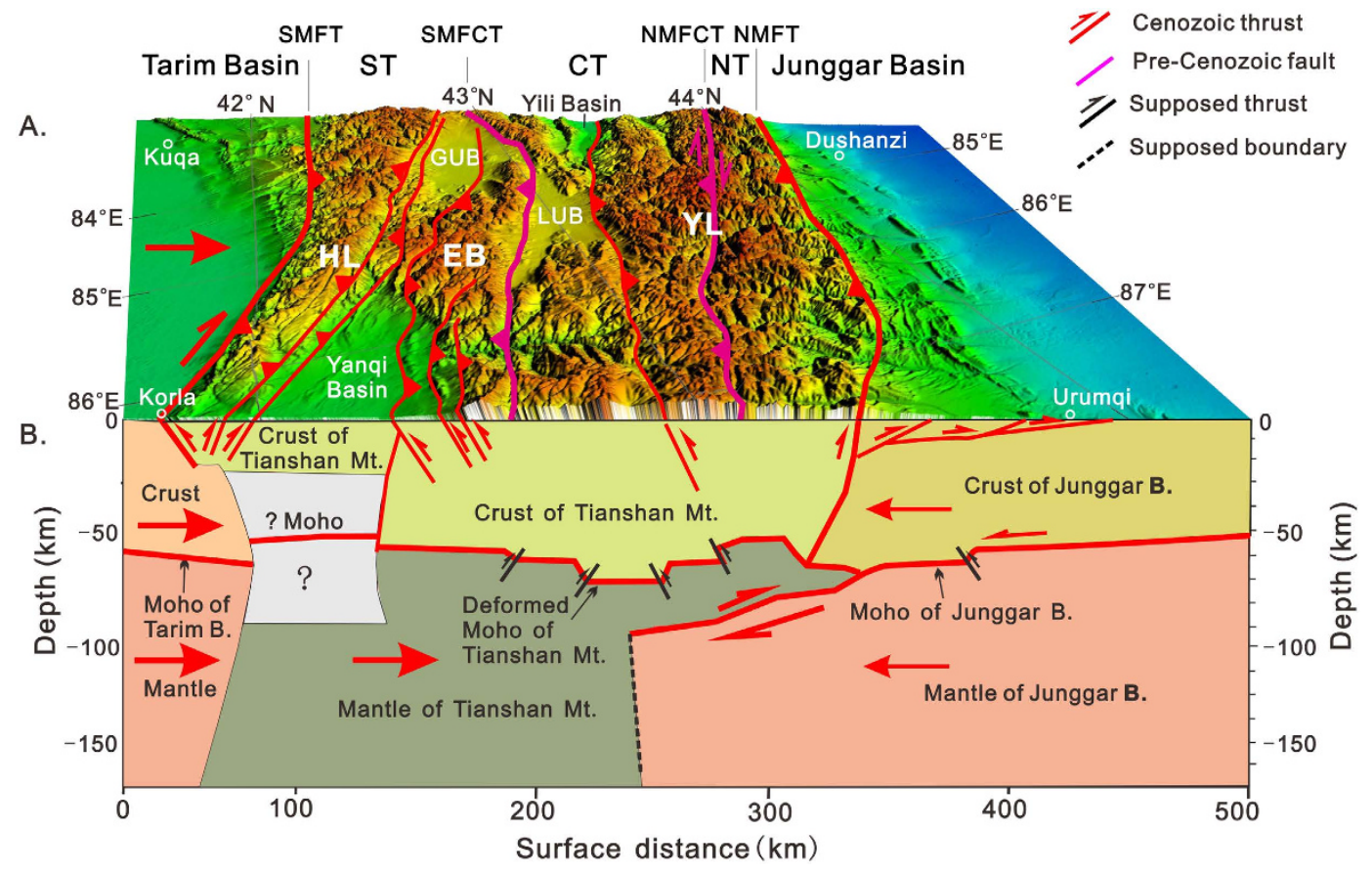

Figure 3. Cartoon map of Segment $\mathbf{C}$ in the Tianshan Mountains. (A) Geomorphologic features of Segment $\mathrm{C}$ in the Tianshan Mountains. (B) Deep structures and the driving mechanism for the uplift of the mountains during the Cenozoic. The abbreviations are the same as those in Fig. 2. The primary DEM data that were used for the geomorphological features in (A) are in the SRTM GTOPO 30 format and were provided by NASA and downloaded from http://glcf.umiacs.umd.edu in 2010. The figure was generated by using ArcMap v10.1 (http:// www.esrichina.com.cn/softwareproduct/ArcGIS/) and processed by CorelDRAW X7 (http://www.coreldraw. $\mathrm{com} / \mathrm{cn} /$ product/graphic-design-software/?hptrack $=\mathrm{cn} 2 \mathrm{hr1}$ \&_ga $=1.59748394 .665041398 .1450858064)$.

including thrusts along the margins of the intermontane basins within the Tianshan Mountains, folds and thrusts in Mesozoic and Cenozoic strata in the northern piedmont of the mountains, and numerous earthquakes with hypocenters at depths of $20 \mathrm{~km}$ or less, implies the occurrence of intense crustal tectonic stacking and shortening in the region. Additionally, intracrustal detachment at approximately $20-30 \mathrm{~km}$ depth and imbricated-thrust structures at $0-12 \mathrm{~km}$ depth under the southern Junggar Basin have been revealed by two deep seismic reflection profiles $^{48,49}$. In contrast, no folds or thrusts that resemble those along the southern margin of the Junggar Basin occur in the southern piedmont region of Segment $\mathrm{C}$ in the mountains.

In summary, available deep-seated structural data from Segment $\mathrm{C}$ in the Tianshan Mountains show a significant difference between northern and southern parts of the mountains, namely, a deep-seated structure, which corresponds to the region's geomophological features. This deep-seated structure beneath the high linear ranges of the northern part is characterized by more complex intracrustal deformation, thicker crust, concave-upward geometry in the Moho, and Moho overlap between the northern Tianshan Mountains and the Junggar Basin. Below the alternate ranges and basins of the southern part of the mountains are simpler intracrustal structures, a nearly flat, local cut-off but no overlap of the Moho, and very limited indentation of the Tarim lithosphere.

The different responses of the southern and northern parts of the mountains to a compressional setting from the collision of the Indian and Eurasian plates may be related to their crustal tectonics and the geometric relationship of the regional compressional stress with respect to the boundaries between the basins and mountains. The crust in the northern part is composed of linear arc complexes to the south and accretionary complexes to the north. The strikes of these complexes and the boundary between the Junggar Basin and the Tianshan Mountains are nearly perpendicular to the direction of the Cenozoic regional compressional stress $\mathrm{s}^{60,61}$ (Fig. 1B). In contrast, the crust in the southern part of the Tianshan Mountains consists of a mosaic of arc and oceanic complexes, and structural styles such as boudinage developed more readily under plane compressional stress in the south-north direction. The boundary between the Tarim Basin and the Tianshan Mountains forms an arc-like line that protrudes northwards, and most parts of the boundary are oblique to the direction of the Cenozoic regional compressional stress (Fig. 1B). Simultaneously, the northward indentation of the Pamir range induced the clockwise rotation of the Tarim Basin. These factors contributed to the development of different local stress fields in the various segments of the boundary.

Based on the above discussion, we propose a new tectonic model for the Cenozoic intracontinental orogenesis of Segment C in the Tianshan Mountains, as shown in Fig. 3. Nearly north-south-oriented stress that originated from the collision of the Indian and Eurasian plates moved the Tarim block northward, pushing the Tianshan lithosphere northward as well. The limited indentation of the Tarim lithosphere into the southern margin of the Tianshan Mountains produced unique geomorphology. The lithosphere of the Junggar Basin uncoupled along the Moho, and its mantle was subducted beneath the Tianshan Moho. This process led to shortening deformation 
in the Tianshan Moho, the structural stacking and thickening of the overlying crust, and the uplift of high, linear mountain ranges in the northern part of the Tianshan Mountains. Simultaneously, the Tianshan mantle was inserted northwards along the Moho into the lithosphere of the Junggar Basin, forming a crocodile mouth-like structural framework at the junction of the Tianshan Mountains and the Junggar Basin. This model, in terms of its size, deep-seated structures, surface geology and geomorphology, especially when considering only the subduction of the mantle part of the lithosphere, is clearly different from the B-type subduction at active continental margins and A-type subduction at collisional belts between two continents. Thus, we suggest that the above model be termed mantle subduction and abbreviated M-type subduction.

The overlap of the Moho beneath the northern part of Segment $C$ of the Tianshan Mountains is not interpreted as a re-activated Paleozoic subduction zone mainly because of the difference in the dipping direction between fossil subduction and the present overlapping Moho and because of the relationship of the deep structures with near-surface ancient tectonics. The available regional geological data show four Paleozoic subduction zones with various subducted polarities in the Tianshan Mountains, and a subduction zone with northward polarity was located south of the Junggar island arc, which has acted as the basement of the Junggar Basin since the Permian $^{11,62}$. Traces of all the subduction zones are not always observed in all the available deep seismic profiles, indicating that these Paleozoic subduction tectonics were only recorded in rocks in the upper part of the crust.

Some geologists have suggested a crustal material cycle model in which erosion drove the uplift of the Tianshan Mountains ${ }^{2,6}$. For this driving mechanism, the geomorphological differences would have to have existed prior to erosion. Therefore, thicker crust and high mountains would need to be already present in the erosion regions, and relatively thinner crust and lower-elevation topography would need to be present in the sedimentary region. The development of these geomorphic differences is not addressed in their models. Uplift that was driven by mantle subduction possibly preceded the crustal material cycle.

High linear mountains that are associated with fold-and-thrust deformation in piedmont regions and are similar to those in Segment C of the Tianshan Mountains are also present in Segment B and possibly in Segment A of the mountains (Fig. 1B). Up to now, images of deep structures have only been reported from Segment B. Earlier investigations of seismic tomography did not uncover any information regarding mantle subduction ${ }^{63-66}$. However, the overlap of the Moho was revealed by a recent N-S-directed explosive-source deep seismic-reflection profile in the southern piedmont region of Segment B in NW Tarim Basin ${ }^{67}$, which indicated small-scale (less than $20 \mathrm{~km}$ ) mantle subduction. In addition, similar Moho overlaps have been reported from the western Qinling and Longmenshan ranges on the northeastern margin of the Qingzang Plateau ${ }^{68-70}$. Furthermore, decoupling along the Moho has been reported beneath some mountain ranges elsewhere on Earth ${ }^{71}$, which implies that mantle subduction likely occurred below those mountains. Simulations of the origin of mountains also reveals similar mantle subduction ${ }^{72}$. This information and data suggest that mantle subduction should be a primary driving mechanism for the uplift of high, linear intracontinental mountains under compressional stresses that are nearly perpendicular to the mountains' strike.

\section{Method}

The field collection of a seismic dataset was conducted between the May 2002 and November 2004, producing a receiver function image of the profile across the Chinese Tianshan Mountains along the highway from Urumuqi to Korla, as part of a broadband teleseismic investigation of eastern Xinjiang from Altay southwards through East Junggar, the Junggar Basin and the Tianshan Mountains to the northern Tarim Basin,. Refteck and Minittan's seismographs which used band ranges of $60-5 \mathrm{~s}$, were used to obtain the dataset. The sites of the seismic stations across Segment C of the Tianshan Mountains were spaced at an interval of 10-15 km, as shown in Fig. 1B. The data processing and formation of the images were conducted by using the same methods as Kind et al. ${ }^{73}$, and the details have been discussed by Li et al. ${ }^{45}$.

\section{References}

1. Miyashiro, A., Aki, K. \& Sengor, A. M. C. Orogeny. John Wiley \& Sons Ltd., 236 p (1982).

2. Avouac, J. P. \& Burov, E. B. Erosion as a driving mechanism of intracontinental mountain growth. J. Geophys. Res. 101, 17747-17769 (1996).

3. Cunningham, W. D. Lithospheric controls on Late Cenozoic construction of the Mongolian Altai, Tectonics 17, 891-902 (1998).

4. Cunningham, W. D., Owen, L. A., Snee L. W. \& Li, J. Structural framework of a major intracontinental orogenic termination zone: the easternmost Tien Shan, China. J. Geol. Soc. Lond. 160, 575-590 (2003).

5. Cunningham, W. D. Active intracontinental transpressional mountain building in the Mongolian Altai: Defining a new class of orogen. Earth Planet. Sci. Let. 240, 436-444 (2005).

6. Vernant, P. et al. Erosion-induced isostatic rebound triggers extension in low convergent mountain ranges. Geology 4, 467-470 (2013).

7. Kennett, B. L. N. \& Iaffaldano, G. Role of lithosphere in intra-continental deformation: Central Australia. Gond. Res. 24, 958-968 (2013).

8. Raimondo, T., Hand, M. \& Collins, W. J. Compressional intracontinental orogens: Ancient and modern perspectives. Earth-Sci. Rev. 130, 128-153 (2014)

9. Windley, B. F., Allen, M. B., Zhang, C., Zhao, Z. Y. \& Wang, G. R. Paleozoic accretion and Cenozoic redeformation of the Chinese Tien Shan Range, Central Asia. Geology 18, 128-131 (1990).

10. Sengor, A. M. C. \& Natal'in, B. Paleotectonics of Asia: fragments of a synthesis. In The Tectonic Evolution of Asia (eds. Yin, A. \& Harrison, T. M.) 486-640. Cambridge, UK: Cambridge Univ. Press (1996).

11. Gao, J., Li, M., Xiao, X., Tang, Y. \& He, G. Paleozoic tectonic evolution of the Tianshan orogen, northwestern China. Tectonophysics 287, 213-231 (1998).

12. Li, J.-Y. et al. Geomorphological features, crustal composition and geological evolution of the Tianshan Mountains. Geol. Bull. China 25, 895-909 (2006).

13. Charvet, J. et al. Palaeozoic tectonic evolution of the Tianshan belt, NW China. Science in China Series D: Earth Sci. 54, 166-184 (2011).

14. Xiao, W., Windley, B. F., Allen, M. B. \& Han, C. Paleozoic multiple accretionary and collisional tectonics of the Chinese Tianshan orogenic collage. Gond. Res. 23, 1316-1341 (2013). 
15. Zhang, P. et al. Late Cenozoic tectonic deformation and mechanism along the Tianshan Mountain, northwestern China. Earthquake Res. China 12, 127-140 (1996).

16. Abdrakhmatov, K. et al. Onset, style and current rate of shortening in the central Tien Shan, Kyrgyz Republic. Russian Geology and Geophysics 42, 1585-1609 (2001).

17. Dumitru, T. A. et al. Uplift, exhumation, and deformation in the Chinese Tian Shan. Geol. Soc. Am. Mem. 194, 71-99 (2001).

18. Thompson, S. C. et al. Late Quaternary slip rates across the central Tien Shan, Kyrgyzstan, central Asia. J. Geophys. Res. 107, 2203, doi: 10.1029/2001JB000596 (2002).

19. Han, Y. J. et al. Thrusts of Hola mountains in Yanqi basin and its evolution. Hennan Petroleum 19, 4-5 (2005).

20. Goode, J. K., Burbank, D. W. \& Bookhagen, B. Basin width control of faulting in the Naryn Basin, south-central Kyrgyzstan. Tectonics 30, TC6009, doi: 10.1029/2011TC002910 (2011).

21. Zhang, J., Li, J.-Y. \& Zhu Z. X. The Late Cenozoic deformation of the Wusunshan mountain in the Yili basin and its significance. Xinjiang Geology 27, 101-105 (2009).

22. Avouac, J. P., Tapponier, P., Bai, M., You, H. \& Wang, G. Active thrusting and folding along the northern Tien Shan and Late Cenozoic rotation of the Tarim relative to Dzungaria and Kazakhstan. J. Geophys. Res. 98, 6755-6804 (1993).

23. Yin, A., Nie S. \& Craig P. Late Cenozoic tectonic evolution of the southern Chinese Tian Shan. Tectonics 17, 1-27 (1998).

24. Burchfiel, B. C., Brown, E. T. \& Deng Q. Crustal shortening on the margins of the Tienshan, Xinjiang, China. Internat. Geol. Rev. 41, 665-700 (1999)

25. Deng, Q. D. et al. Reverse fault and fold zone in the Urumqi range-front depression of the norther Tianshan and its genetic Mechanism. Earth Sci. Front. 6, 191-201 (1999).

26. Allen, M. B., Vincents, S. J. \& Wheeler, P. J. Late Cenozoic tectonics of the Kepingtoge thrust zone: interaction between the Tian Shan and the Tarim Basin, northwest China. Tectonics 18, 639-654 (1999).

27. Chen, J. et al. Magnetochronology of the Upper Cenozoic strata in the Southwestern Chinese Tian Shan: rates of Pleistocene folding and thrusting. Earth Planet. Sci. Let. 195, 113-130 (2002).

28. Fu, B. H., Lin, A. M., Kano, K., Maruyama, T. \& Guo, J. M. Quaternary folding of the eastern Tian Shan, northwest China. Tectonophysics 369, 79-101 (2003).

29. Buslov, M. M., Grave, J. D. \& Bataleva, E. A. Cenozoic tectonics and geodynamic evolution of the Tien Shan mountain belt as response to India-Eurasia convergence. Himalayan J. Sci. 2, 106-107 (2004).

30. Charreau, J., Avouac, J.-P., Chen, Y., Dominguez, S. \& Gilder, S. Miocene to present kinematics of fault-bend folding across the Huerguosi anticline, northern Tianshan (China), derived from structural, seismic, and magnetostratigraphic data. Geology 36, 871-874 (2008)

31. Yang, X., Deng, Q., Zhang, P. \& Xu, X. Crustal shortening of major nappe structures on the front margins of the Tianshan. Seis. Geol. 30, 111-131 (2008)

32. Yin, A. Cenozoic tectonic evolution of Asia: A preliminary synthesis. Tectonophysics 488, 293-325 (2010).

33. Li, Y. P., Li, J. Y., Sun, G. H., Zhu, Z. X. \& Yang, Z. Q. The Basement of Junggar basin: evidence from detrital zircons in sandstone of previous Devonian Kalamaili formation. Acta Petrol. Sin. 23, 1577-1590 (2007).

34. Lu, S. N., Li, H. K., Zhang, C. L. \& Liu, G. H. Geological and geochronological evi-dences for the Precambrian evolution of the Tarim Craton and surrounding continental fragments. Precambrian Res. 160, 94-107 (2008).

35. Molnar, P. \& Tapponnier, P. Cenozoic tectonics of Asia: Effects of a continental collision. Science 189, 419-426 (1975).

36. Tapponier, P. \& Molnar, P. Active faulting and Cenozoic tectonics of Tien Shan, Mongolia and Baikal regions. J. Geophys. Res. 84, 3425-3459 (1979).

37. Hendrix, M. S., Dumitru, T. A. \& Graham, S. A. Late Oligocene-early Miocene unroofing in the Chinese Tian Shan: an early effect of the India-Asia collision. Geology 22, 487-490 (1994).

38. Cobbold, P. R. \& Davy, P. Indentation tectonics in nature and experiment. 2. Central Asia. Bull. Geol. Inst. Uppsala, N. S. 14, 143-162 (1988).

39. Zhao, J. M., Liu, G. D., Lu, Z. X., Zhang, X. K. \& Zhao, G. Z. Lithospheric structure and dynamic processes of the Tianshan Orogenic Belt and the Junggar Basin. Tectonophysics 376, 199-239 (2003).

40. Chen, Y. et al. Paleomagnetic study of Mesozoic continental sediments along the Northern Tianshan (China) and heterogeneous strain in central Asia. J Geophys. Res. 96, 4065-4082 (1990).

41. Liu, J., Liu, Q. Y., Guo, B., Yuen, D. A. \& Song, H. Z. Small-scale convection in the upper mantle beneath the Chinese Tian Shan Mountains. Phys. Earth Planet. Inter. 163, 179-190 (2007).

42. Langston, C. A. \& Corvallis O. Crustal and upper mantle receiver structure from teleseismic P and S waves. Bull. Seism. Soc. Am. 67, 713-724 (1977).

43. Vinnik, L. P. Detection of waves converted from P to SV in the mantle. Phys. Earth Planet. Inter. 15, 39-45 (1977).

44. Cassidy, J. F. Numerical experiments in broadband receiver function analysis. Bull. Seismol. Soc. Am. 82, 1453-1474 (1992).

45. Li, H. O., Jiang, M., Wang, Y. J., Zhang, L. S. \& Yu, G. X. Image of Crust and upper mantle structure along the array from Fuyun to Kuerle by P- to- S Converted Waves. Acta Geol. Sin. 80, 135-141 (2006).

46. Wang, Y. J. et al. Image of crust and upper mantle velocity structure along the array from Fuyun to Kuerle by Seismic Tomography. Acta Geol. Sin. 80, 142-147 (2006).

47. Lin, G. L. \& Liu, C. Y. Basic characteristics of deep-seated tectonics in Xinjiang. Xinjiang Geology 13, 56-66 (1995).

48. Liu, B. J. et al. The crust structures and tectonics of Urumqi depression revealed by deep seismic reflection profile in the northern margin of Tianshan Mountains. Chinese J. Geophys. 50, 1464-1472 (2007).

49. Wang, C. Y., Yang, Z. E., Luo, H. \& Mooney, W. D. Crustal structure of the northern margin of the eastern Tien Shan, China, and its tectonic implications for the 1906 M 7.7 Manas earthquake. Earth Planet. Sci. Let. 223, 187-202 (2004).

50. Zhou, S. Y. \& Sulaiman, B. Paleogeography of the Cretaceous in Xinjiang. Xinjiang Geol. 18, 347-351 (2000).

51. Woodward, N. B., Boyer, S. E. \& Suppe, J. Balanced Geological Cross-Sections: An Essential Technique in Geological Research and Exploration. Short Course in Geology: Volume 6, pp. 131, Presented at the $28^{\text {th }}$ International Geological Congress, Washington, D.C., American Geophysical Union, Washington, D.C. (1989).

52. Shao, X. Z. et al. The crust structures of Tianshan orogenic belt: a deep sounding work by converted waves of earthquakes along Urumqi-Korla profile. Acta Geophysica Sinica 39, 336-346 (1996).

53. Mi, N. et al. Velocity structure of the crust and uppermost mantle in the boundary area of the Tianshan Mountains and the Tarim Basin. Chinese Sci. Bull 50, 270-275 (2005).

54. Lu, D. Y. et al. A deep seismic sounding profile across the Tianshan Mountains. Chinese Sci. Bull 45, 2100-2106 (2000).

55. Wei, S. H. et al. Xinjiang Kuche-Kelamayi Seismic Tomography. Prog. Geophys. 15, 46-54 (2000).

56. Poupinent, G. et al. Intracontinental subduction and Palaeozoic inheritance of the lithosphere suggested by a teleseismic experiment across the Chinese Tien Shan. Terra Nova 14, 18-24 (2002).

57. Guo, B. et al. Seismic tomography of the crust and upper mantle structure underneath the Chinese Tianshan. Chinese J.Geophys. 49, 1543-1551 (2006).

58. Li, Y. et al. Shear wave velocity structure of the crust and upper mantle underneath the Tian Shan orogenic belt. Sci. China Ser. D: Earth Sci. 50, 321-330 (2007).

59. Nelson, M. R., McCaffrey, R. \& Molnar, P. Source parameters for 11 earthquakes in the Tien Shan, Central Asia, determined by $\mathrm{P}$ and SH waveform inversion. J. Geophys. Res. 92, 12629-12648 (1987). 
60. Zhang, P. et al. Continuous deformation of the Tibetan Plateau from global positioning system data. Geology 32, 809-812 (2004).

61. Niu, Z. J. et al. Contemporary velocity field of crustal movement of Chinese mainland from Global Positioning System measurements. Chinese Sci. Bull 50, 939-941 (2005).

62. Li, J. Y., Xiao, W. J., Wang, K. Z., Sun, G. H. \& Gao, L. M. Neoproterozoic-Paleozoic tectonostratigraphy, magmatic activities and tectonic evolution of eastern Xinjiang, NW China. (Eds. Mao, J. W. et al.), Tectonic Evolution and Metallogeny of the Chinese Altay and Tianshan, IAGOD Guidebook Series 10. CERCAM/NHM, 31-74 (London, 2003).

63. Vinnik, L. P. et al. Receiver function tomography of the central Tien Shan. Earth and Planet. Sci. Let. 225, 131-146 (2004).

64. Lei, J. S. \& Zhao, D. P. Teleseismic P-wave tomography and the upper mantle structure of the central Tien Shan orogenic belt. Phys. Earth Planet. Inter. 162, 165-185 (2007).

65. Omuralieva, A., Nakajima, J. \& Hasegawa, A. Three-dimensional seismic velocity structure of the crust beneath the central Tien Shan, Kyrgyzstan: Implications for large- and small-scale mountain building. Tectonophysics 465, 30-44 (2009).

66. Guo Z. et al. S-wave velocity of the crust around Tianshan mountains inverted from seismic ambient noise tomography. Chinese Science Bulletin 55, 3590-3598 (2010).

67. Gao, R. et al. Fine crustal structure beneath the junction of the southwest Tian Shan and Tarim Basin, NW China. Lithsphere 5, 382-392 (2013).

68. Gao, R. et al. The crust structures and the connection of the Songpan block and West Qinling orogen revealed by the Hezuo-Tangke deep seismic reflection profiling. Tectonophysics 634, 227-236 (2014).

69. Ye, Z. et al. Seismic evidence for the North China plate underthrusting beneath northeastern Tibet and its implications for plateau growth. Earth Planet. Sci. Let. 426, 109-117 (2015).

70. Guo, X. et al. Imaging the crustal structure beneath the eastern Tibetan Plateau and implications for the uplift of the LongmenShan range. Earth Planet. Sci. Let. 379, 72-80 (2013).

71. Cook, F. A. \& Varsek, J. L. Orogen-scale decollements. Rev. Geophys. 32, 37-60 (1994).

72. Beaumount, C., Fullsack, P. \& Hamilton, J. Styles of crustal deformation in conmpressional orogens caused by subduction of the underlying lithosphere. Tectonophysics 232, 119-132 (1994).

73. Kind, R. et al. Seismic Images of Crust and Upper Mantle Beneath Tibet: Evidence for Eurasian Plate Subduction. Science 298, $1219-1221$ (2002).

\section{Acknowledgements}

This study was financially supported by China's State Key Basic Research and Development Project (grant No. 2001CB409810, 2007CB411306), China Geological Surveys (grant No.1212010611806, 1212011085476, 12120114064301) and Natural Science Foundation of China (grant No. 41272243). Sincere thanks are presented to two anonymous reviewers for their constructive suggestions.

\section{Author Contributions}

J. Li contributed to idea development, data compilation and organized field geological works. J. Li, J.Z. and X.Z. discussed and wrote the manuscript text, J. Li, J.Z., Y.T., G.S., Y.L., Z.Z., Q.F., L.W. and J. Liu contributed to field data-collection of structural deformation, discussed the manuscript, and prepared the figures. M.J. organized field collection and processes of the seismic data, and formation of the receiver function image.

\section{Additional Information}

Competing financial interests: The authors declare no competing financial interests.

How to cite this article: Li, J. et al. Mantle Subduction and Uplift of Intracontinental Mountains: A Case Study from the Chinese Tianshan Mountains within Eurasia. Sci. Rep. 6, 28831; doi: 10.1038/srep28831 (2016).

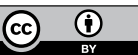

This work is licensed under a Creative Commons Attribution 4.0 International License. The images or other third party material in this article are included in the article's Creative Commons license, unless indicated otherwise in the credit line; if the material is not included under the Creative Commons license, users will need to obtain permission from the license holder to reproduce the material. To view a copy of this license, visit http://creativecommons.org/licenses/by/4.0/ 